\title{
Geology Behind Barbed Wire: James Alfred Richardson (1914-2007) and the Richardson Award of the Geologists' Association
}

\author{
Richard J. Howarth* \\ Department of Earth Sciences, University College London, London WC1E 6BT, UK \\ * Tel: +44 (0)7532269916. E-mail address: r.howarth@ucl.ac.uk
}

\section{ABSTRACT}

The Richardson Award, for the best paper published annually in the Proceedings of the Geologists' Association, was established in 1996. This paper describes the life of the Richardson family: James ('Jim') Richardson, the instigator of the Award, his wife Doris and their only son, Gwyn (who died in infancy). The focus is mainly on Richardson's education in the United Kingdom and early career as a field and mining geologist with the Geological Survey Department of the Federated Malay States (Malaysia) and how, having been caught up in WWII, he and his geological colleagues kept thoughts of geology alive during their time as Prisoners of War under the Japanese in Singapore, Thailand and Burma (1942-45). One of the relatively few survivors of the infamous 'Death Railway', his subsequent career as a petroleum geologist in the Netherlands, Venezuela, USA and Australia; and as a geologist involved in mineral exploration, artist and local historian in Australia is also described.

Keywords: Biography, Far-Eastern POWs, Malaysia, Thailand, Venezuela, Australia.

\section{Introduction}

In 1996, the Geologists' Association (GA), originally established in 1858 for the benefit of 'students of the science of Geology ... who are actively engaged in looking into Nature' with a particular emphasis on Geology in the Field (Sweeting, 1958, pp. 3-6), was given the sum of $£ 5000$ (the equivalent of c. $£ 8400$ in 2015) in the names of James Alfred Richardson [1914-2007] (Fig.1), Doris Maud Richardson [née Docwra, 19142003] and John Victor [Gwyn]

Richardson [1946-48], to establish an award for the best paper published each year in the Proceedings of the Geologists Association (PGA). First established in 1859 , the journal became an annual periodical in 1911.

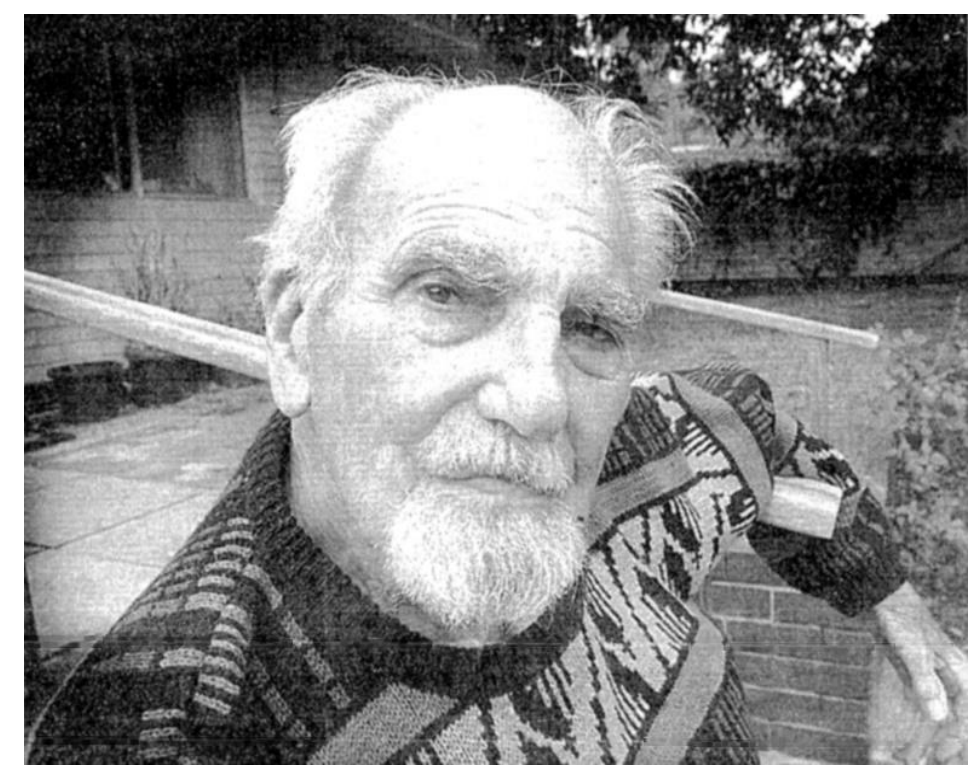

Fig. 1. Richardson at 90, Kalamunda, Western Australia. Reproduced with permission of the Community Newspaper Group, Perth, W.A., from the Kalamunda Reporter, June 1, 2004, p. 4.

When writing a recent update to Sweeting's (1958) history of the GA (Leake et al., 2013) it was realised with considerable embarrassment that, apart from their names, absolutely nothing was known about the three people named in connection with the Richardson Award, nor their relationships ${ }^{1}$, despite James Richardson having been a member of the Association since 1934. This paper is an attempt to rectify that omission. Its main focus is on Richardson's time as a young geologist, and the efforts that both he and his fellow geologists made to keep the subject alive in their minds under conditions of extreme privation

\footnotetext{
${ }^{1}$ Unfortunately, no papers to do with establishment of the Award now appear to exist in the GA archives.
} 
during their captivity by the Japanese in 1942-45. More background information has been included than is perhaps conventional in a geological biography, in order to give as complete a picture as possible of what conditions were like, both when undertaking geological mapping in Malaysia in the 1930s, and during the subsequent years of WWII in the Far East.

\section{Early years}

James Alfred ('Jim') Richardson was born on 30 May 1914, at 59 Gilbey Road, Tooting, London, to Hannah Amelia Richardson (1880-1960; née Lever) and her husband, Alfred George Richardson (1882-1962), a journeyman house-painter and builder. His father's absence during Richardson's formative years as the result of his service in the Royal Engineers (1915-18) in WWI, appears to have caused a distancing between them which never changed. Richardson's sister, Joan Mary, was born in 1920, but they too do not seem to have been particularly close.

Richardson started at a local elementary school in 1920 and by 1924 he was in the senior boy's school where he was taught by, among others, Ernest Arthur George Turner (1878-1971). Turner was an enthusiastic amateur geologist and had been a member of the GA since 1916 and was also a Fellow of the Geological Society of London (GSL, FGS) (192039). During the 1920s and 1930s, Turner was an active member of the GA's Weald Research Committee (WRC), founded in 1923 to increase knowledge of this region of south-east England. Its members undertook both 6 in: $1 \mathrm{mi}$ scale (1:10,560) geological mapping of selected areas as well as detailed investigations of stratigraphy and geomorphology (Kirkaldy, 1958; Sweeting, 1958, pp. 18-19). Turner was one of the co-authors of a WRC report on the geomorphology and stratigraphy of the River Mole (Bull et al., 1934), which flows into the River Thames near Hampton Court; and he led GA excursions to Kingston Hill, Cobham, Walton Heath, Guildford, Witley and Hascombe in Surrey. Richardson was captivated: Turner introduced him to the fascination of rocks and fossils, gave him specimens and books and, aged ten, he decided to become a geologist (Richardson, 1985, p. 2$)^{2}$.

In 1926, Richardson entered the newly-established (Sir Charles) Elliott Central School, Southfields, in Wandsworth, London, where the Geography master, Dr. Rees Ogwyn Jones (1904-1973), FGS, was a recently-graduated geologist from Swansea University who, having been unable to find a geological job, had become a schoolmaster. Jones joined the GA in 1927 and the GSL in 1928, and took Richardson along when he went to their meetings. Jones was eventually appointed to the staff of the Geological Survey and Museum, London, in 1936.

Following this encouraging start, in 1931 Richardson was successful in obtaining a London County Council Scholarship and in the Autumn of that year entered the Science Sixth form at Westminster City School, one of the few to formally include Geology in its curriculum. Here he was taught the subject by Dr. Leonard Miles Parsons (1883-1956), FGS, a graduate of the Imperial College of Science and Technology (ICST), London, who had joined the school staff in 1916, and would retire in 1940 (H.D.T., 1958). At the same time, Richardson was also taking evening classes in Chemistry and Geology at the Chelsea Polytechnic, where he was taught by Dr. [Arthur] John Maslen (1871-1954), FGS, a

\footnotetext{
${ }^{2}$ To avoid undue repetition, page references to Richardson's unpublished memoir are hereafter cited as 'M 2', etc.
} 
paleobotanist and outstanding teacher, who had established the Polytechnic's Department of Geology in 1900 (W.B.T., 1954). At the end of his first year, Richardson came first in the school examinations in both Chemistry and Geology, and was awarded prizes in these subjects. During the following year, he was successful in gaining a Royal Scholarship to the ICST and did sufficiently well in his final Higher School Certificate Examination, to gain exemption from the College's Intermediate BSc Examination. Consequently, in October 1933, he was able to enter the ICST's Royal College of Science in the second year of a fouryear course.

Its Department of Geology was at that time headed by Prof. Percy George Hamnall Boswell FRS (1886-1960), an applied sedimentologist, whose his staff consisted of: Palaeontology: Asst. Prof. Arthur Morley Davies (1869-1959) and Dr. (Walter) Frederick Whittard (1902-1966), who took over from Morley Davies on his retirement in 1935, with Dr. Alan Wood (1910-1992) as Demonstrator; 'Petrological Geology': Prof. Alfred Brammall (1874-1954); Structural Geology: Gilbert Wilson (1899-1986); Mining Geology: Prof. Charles Gilbert Cullis (1871-1941) and Prof. William Richard Jones (1890-1970); Petroleum Technology: Prof. Vincent Charles Illing (1890-1969); Engineering Geology: Francis George Henry Blyth (1904-1993); and the Librarian in charge of the Department's large book and pamphlet collection: George Scotland Sweeting (1889-1997). All, apart from Cullis and Jones, were members of both the GSL and the GA. Sweeting was at that time Editor (19321946) of the PGA and had previously been Secretary (1923-1931) of the WRC.

At the end of his first scholastic year, Richardson was awarded the Murchison Prize and Medal for Geology. He then spent the Summer Vacation of 1934 on fieldwork in Shropshire and Herefordshire (classic Whittard territory) together with an Oil Technology student, Henry ('Harry') Samuel Rogers ${ }^{3}$ (1910-2002), and then on his own in the Gower Peninsula, South Wales. That same year, Richardson joined the GA and became a member of the WRC. Between 1934 and 1936, he and Rogers, in their spare-time, undertook 1:10,560scale mapping of a $52 \mathrm{mi}^{2}\left(135 \mathrm{~km}^{2}\right)$ area of the north-west Weald (around Thursley, Witley, Binstead and Bordon; all near Guildford, Surrey). In 1936, they carried out grain-size analysis of samples taken from the Lower Greensand at a number of localities in the same area to assist in the stratigraphic identification of individual units within this formation (Richardson, 1947a; Rogers and Richardson, 1947; Middlemiss, 1975).

Prior to the Summer vacation of 1935, Richardson was invited by Jones to act as his assistant in the elucidation of the geology of the Beralt Tin and Wolfram Ltd. Mine (now the Sojitz Beralt Tin and Wolfram (Portugal) S.A. mine) at Panasqueira in central Portugal, which is still the largest producer of tungsten in the country. Jones remained on site for two weeks, after which Richardson was on his own, mapping underground and on the surface for the next three months (M 9-10).

During his years in the Department, as well as geological studies, Richardson made time to 'read widely in ethnology, anthropology and sociology' as, realising that any geological job would probably entail working overseas, he 'tried to gain some understanding of the inhabitants of, and conditions within tropical lands' (M 11). In addition, throughout the course, he assisted a deaf-mute student, (Bernard) Lewis Pitcher (1909-2000) who would

\footnotetext{
${ }^{3}$ Rogers subsequently changed his surname to Taylor-Rogers (London Gazette, 19 September 1952, p. 4994) and is referred to as such in Richardson (1985).
} 
become the first congenitally deaf person in the UK to obtain a University degree (Williams, 1963, p. 60; Eagling, 2010). Despite all this, in his final year, Richardson was also Secretary of the Department's De La Beche Club which, from 1928 onwards, acted as a social hub open to both staff and students, and organised field-trips and extra-curricular lectures (Williams, 1963, p. xxii).

During the Winter 1935/6 and Easter 1936 vacations, Richardson undertook mapping in an area on the north-eastern flanks of Snowdonia. He was awarded First Class Honours in the Final Examination of 1936 and the Sir Clement Neve Foster Prize, as well as the Watts Medal for fieldwork for 1936 (which his colleague Rogers had been awarded the previous year).

Before joining the permanent staff of the ICST in 1926, Jones had served (1912-15) as an Assistant Geologist in the Geological Survey Department of the Federated Malay States $^{4}$ (GSFMS). He had worked on the origin of the alluvial tin deposits and was subsequently concerned with tungsten mining in Burma before becoming a consultant to a number of mining companies in the Far East (Williams, 1963, pp. 18, 20, 33, 73). He now drew Richardson's attention to a vacancy for a Field Geologist in the GSFMS. Richardson applied, with Jones' recommendation, and in October 1936 he was offered a four-year initial contract.

In the interim, Richardson spent a month becoming familiar with underground tinmining at the Cambourne School of Mines, Cornwall, followed by a month back at the Royal College of Science, learning microchemical analysis (M 13). He was already familiar with the techniques of ore-microscopy, which uses light reflected from the surface of polished sections of ore-bearing rock, as this had been taught to him by Jones, who had introduced a course on the subject in 1930 (Williams, 1963, p. 73). Before leaving, he also enrolled as an external Ph.D. student at London University in the expectation that, at some point, his future career would provide suitable material for a thesis (M 21).

Pitcher remained at ICST and would go on to obtain a Ph.D. degree in invertebrate palaeontology in 1939 (again becoming the first to obtain this distinction; Eagling, 2010) while Rogers joined the North Venezuelan Petroleum Co. as an Exploration Geologist (Watson, 1947, p. 209).

In his final month before going overseas, Richardson became engaged to Doris Maud Docwra (1914-2003); their father's knew each other, and Doris and Jim had been close friends since they were both aged 14. Then, on New Year's Day 1937, he left from Tilbury Docks, Essex, on the steamship SS Carthage bound for Malaya (renamed Malaysia in 1963).

\section{Into the jungle}

After a 27-day journey he arrived at Georgetown on Penang Island, took a ferry across the Malacca Straits to the mainland and travelled southwards by train to Batu Gajah (Fig. 2) where the GSFMS headquarters was. Here he was met by its Director, Eric Stewart ('Bill')

\footnotetext{
${ }^{4}$ At that time the administrative areas of Malaya consisted of: (1) the Crown Colony of the Straits Settlements (SS): Singapore, Penang, Province Wellesley and Malacca; (2) the Federated Malay States (FMS): Perak, Pahang, Selangor and Negri Sembilan; and (3) the Unfederated Malay States (UMS): Kedah, Kelantan, Johore, Trengganu and Perlis.
} 
Willbourn (1889-1971), and two of his future colleagues: Dr. Frank Tinley Ingham (1895-1967), Mining Geologist; and Joseph Charles Shenton (1884-1951), Chemist.

Richardson spent the next month in Batu Gajah, being introduced to the local geology, visiting alluvial tin workings and an underground scheelite mine and, in the Survey's office, examining rock thin-sections and mineral concentrates under the microscope. Then, together with two of the Survey's rock-collectors, Che ${ }^{5}$ Kasim bin Majid and Che Uda Mat Win bin Manas, he transferred to Kuala Lipis, the capital of Pahang State (Fig. 2), where they were to establish a new Survey outpost and begin mapping some $2500 \mathrm{mi}^{2}$ (6475 $\mathrm{km}^{2}$ ) of jungle-covered terrain at 1 in: $1 \mathrm{mi}(1: 63360)$ scale:

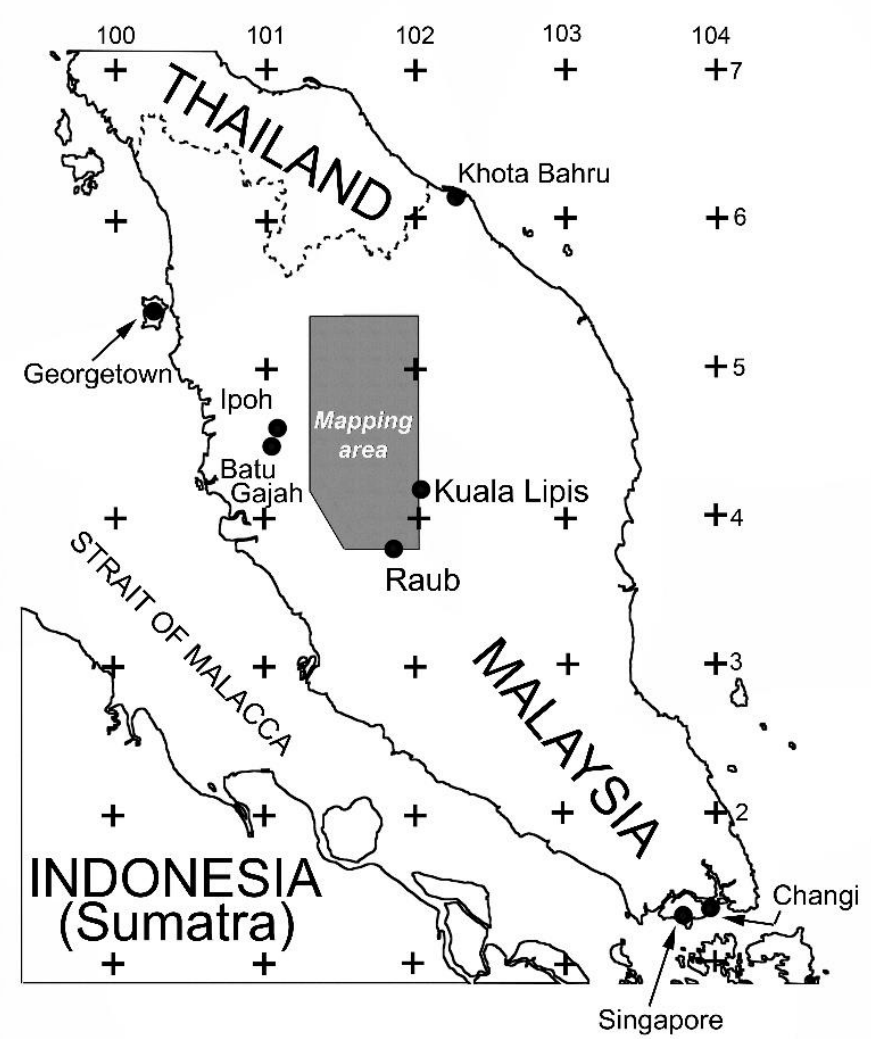

Fig. 2. Malaysia location map.

[The] survey territory extended from the crest of the Main Range which forms the spine of the Malayan Peninsula eastwards to the flood-plain of the Tantum and Lipis Rivers to just east of the [SingaporeKelantan-Terengganu] railway line. The elongate massif of this Main Range trends more or less north-south and is separated by a broad valley from the Foothills Range which parallels it. Then still farther to the east, groups of limestone hills rise perpendicularly from the lowlands; they present a spectacular topography [which could in places reach up to $6000 \mathrm{ft}$ (1830 m) elevation]. (M 48).

Something of a loner at this stage in his life (Richardson 1945, p. 53) ${ }^{6}$, in contrast to the majority of the twenty-two other Europeans in Kuala Lipis 'who felt cut-off and hemmed-in by an environment they saw as hostile,' (M 26-27) Richardson thoroughly enjoyed working in the jungle and was often away with his rock-collectors and support staff for two to three weeks at a time, with only short spells at base.

\begin{abstract}
Most of the survey area was blanketed by jungle with individual trees reaching heights of 150-200 ft [45-60 $\mathrm{m}]$. In some areas the jungle had been replaced by rubber trees and in parts ... by tea plantations. The occupied valley plains were devoted to ricefields, vegetables and fruit gardens. In some areas the forest had little undergrowth, in others it was densely thicketted. A few lines of almost vertical-sided limestone hills stood out of the tree blanket, but these were also copiously vegetated. The combination of luxuriating vegetation, about 100 inches [ $250 \mathrm{~mm}$ ] of rain annually [thunderstorms occur on $70 \%$ of days], the deeply penetrating effects of chemical weathering induced by high temperatures $\left[21-33^{\circ} \mathrm{C}, 70-92^{\circ} \mathrm{F}\right]$ and humidity [56-100\%] [meant] that over most of the terrain no recognisable rocks remained: everything was reduced to soft clay covered by rotting humus. Even where jungle giants were felled by lightening strikes, by violent winds, or by old age, the great rents they made in the subsoil yielded no recognisable rocks. ... It is dimly lit, ... damp and warm to hot; sometimes after heavy rain so stifling one can scarcely breathe. One is permanently soaked with sweat while working and this cools just enough to make one feel chilly round the
\end{abstract}

\footnotetext{
${ }^{5}$ A Malay title by inheritance.

${ }^{6}$ Page references to Richardson's unpublished wartime diary entries are hereafter cited as 'D 53', etc.
} 
neck. ... One becomes pallid for no sunshine breaks through the dense leaf canopy spread above one's head. Only where the terrain is broken by a broad stream or by a major river does sunlight reach the earth and warm the rocks: here we could rest awhile, bask in the warmth and dry off. ... Then back again into the dim, dank humidity. We were mobile units, seldom maintaining camp for more than two nights and then only when several tributaries came together. ... We seldom saw any birds but we could hear them high in the trees. The cicadas provided a deafening accompaniment night and morning to the high-pitched ululations of the [Gibbon apes]; as they brachiated in graceful sweeps from branch to branch high in the canopy. ... Periodically around full-moon, there would be a night or two that was really cold: so cold in fact, that the Malays lit fires in their shelter to try to keep warm and I shivered beneath my thin blanket. (M 32). Animal activity was generally heard, but not seen; most dangerous were elephants, which could trample unaware through a campsite in the night, although tigers and bears were occasionaly encountered. Among smaller creatures, mosquitos and ticks were the most dangerous as carriers of disease, and leeches were a major nuisance (M 50-52). ${ }^{7}$

Only in the river beds and along their banks within the jungle could one hope to find rock in situ and still sufficiently fresh to be identified; and many sections of the rivers yielded little or no information. The only other sources of useful data were the very few open-cut gold mines operating and cuttings along the few roads which traversed [the area] (M 31).

The general method of working was to make east-west traverses across the broad strike of the rocks and north-south along the main longitudinal rivers. Detail was then infilled by examining each drainage basin in turn (Richardson, 1950, p. 4).

Consequently, on all our field expeditions, we spent a considerable portion of each day, sometimes all day from 7 am until $4 \mathrm{pm}$ [when the evening rains began] wading up creeks and streams; collecting such rocks as were visible; measuring their dip and strike directions, panning gravels for their heavy-mineral, gold and tin ore content and in the process becoming very weary and chilled from the waist down while sweating copiously from the waist up. Although the inner jungle ranged between about $82-84^{\circ} \mathrm{F}$ [28-29 $\left.{ }^{\circ} \mathrm{C}\right]$ with relative humidity around 90 percent or more, it was remarkable how cold the clear running streams would become after several hours immersion. (M 31).

Mapping proceeded by wading up streams or along narrow paths they cleared through the undergrowth: With their bush-knives the 'Malays cleared just enough space to proceed through the undergrowth, dense along the stream's sides. ... Spiny palms snagged one's clothes; loops of rotan, multi-spined, laced across one's face; roots tried to trip one up and every so often a low-level branch would whip my hat off. Progress was slow.' (M 29). However, the rivers and streams were occasionally broad and deep enough that they could be navigated by bamboo raft or a boat with an outboard motor. Any outcrops encountered would be sampled, numbered, and located on the topographic base-maps as accurately as possible ${ }^{8}$. Heavy mineral concentrates were also panned from the alluvium for later microscopical examination for the presence of ore minerals such as gold, tin, cinnabar, ilmenite and manganite (Richardson 1939a).

Initially, both Che Uda and Che Kasim accompanied Richardson. However, once they had gained sufficient experience, they were entrusted to lead field parties themselves. These mapped independently, while he was working elsewhere or report-writing. He would subsequently visit the streams they had surveyed and check the records obtained (Fig. 3). 'The method functioned well. I always believe in developing responsibility in staff and giving full credit to individuals for their achievements' (M 34).

\footnotetext{
${ }^{7}$ Further insight into conditions in Richardson's field area is given by Chapman's (1949) account of irregular action behind Japanese lines, as much of the guerilla action took place over the same ground.

${ }^{8}$ See Evans (1932) for an account of field methods used when mapping in comparable Burmese jungle for which no base-maps were available.
} 
Apart from the regional survey, Richardson's other task was to make a detailed geological map of the area surrounding the Raub Australian Gold Mine (Fig. 2) and of its underground workings. Although near-surface workings in the Raub area stretched back into antiquity, the present-day mine was begun in 1889 , when it first became possible to dewater workings below the $50 \mathrm{ft}$ (15 m) water-table. Then, in 1893, its British-born Australian minemanager, William Bibby (1837-1900) found 'an enormously rich [ore] chute' in a new shaft he was sinking (Anonymous, 1900; Richardson, 1939b). The mine soon became the major producer of its day in Malaysia. However, underground operations ceased in 1961 and it has since been mined using open-pit working (ACA Howe International Ltd., 2005).

Richardson undertook the mine survey during the October-January rainy seasons of 1937 and 1938, when rivers would run in spate covering any possible outcrops, while Che Uda and Che Kasim stayed in Kuala Lipis making thin-sections of specimens gathered in the regional survey (M 31).

The earliest geological investigation at Raub had been undertaken in 1911 by John Brooke Scrivenor (1876-1950), the first Director of the GSFMS (Scrivenor, 1928), but a far more detailed examination was now required to guide future exploration, as the neither the structure nor the petrology of the goldbearing quartz reefs, veins and stringers had ever been examined in detail.

Beginning in 1893, successive levels had been opened at $100 \mathrm{ft}(30 \mathrm{~m})$ intervals, but by 1937:

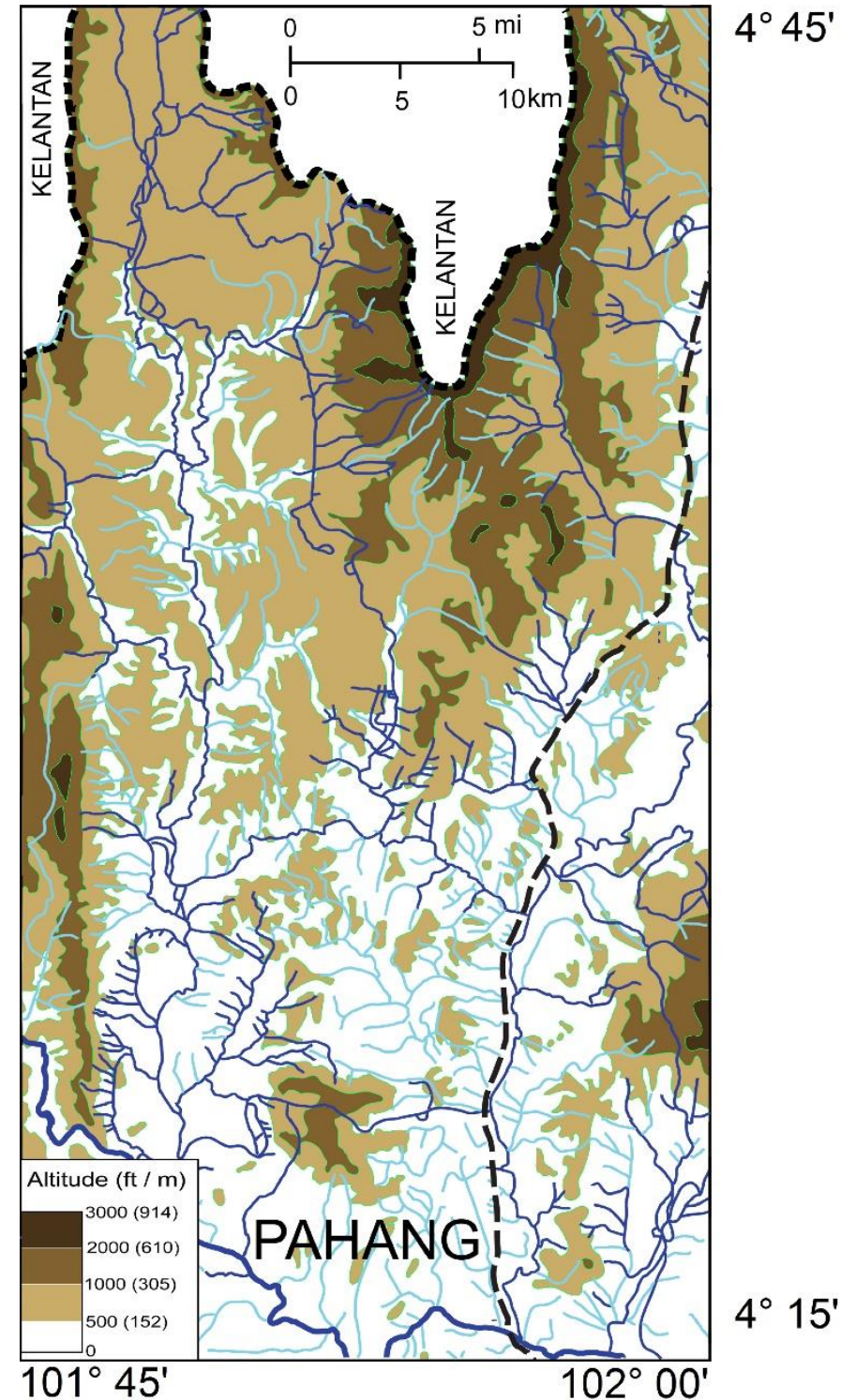

Fig. 3. Topography and drainage, Pahang State, Malaysia. Dark blue rivers: those surveyed by Richardson; light blue rivers: those surveyed by trained rock-collectors and checked by Richardson. Track of (former) Kuala Lipis - Merapoh railway also shown. Adapted from Richardson (1950), Figs. 3 and 4, with permission of the Jabatan Mineral dan Geosains Malaysia.

the $100 \mathrm{ft}$ and $200 \mathrm{ft}$ levels were so dangerous that they could not be surveyed. ... So [Richardson] started on the $300 \mathrm{ft}$ and worked systematically south to north, east to west and up and down along each level until the [deepest] $1000 \mathrm{ft}\left(10^{\text {th }}\right)$ level was completed. This involved detailed mapping, literally foot by foot in some critical sectors, through many miles of tunnels. The overall length north-south of the workings was about $31 / 2$ miles $[51 / 2 \mathrm{~km}]$ and there were eastern and western lode systems with stockwork excavations like an orange box between them. So the project involved a very great deal of work. The mine was wet; average humidity was about $100 \%$ and the temperature was high ... in dead ends one just sweltered and poured with sweat [while trying to avoid the] very large cockroaches swarming in some areas (M 39). 
In addition to elucidating the detailed structure of the mine and the petrography of the rocks involved, Richardson (Fig. 4) recognised the importance of hydrothermal fluids in the development of the quartz-carbonate-vein gold deposits. Some thin-sections of rocks from the district must have been sent back to ICST for photography, as the photomicrographs in Richardson (1939b, Plates I-III) are all attributed to Sweeting. However,

Richardson introduced the technique of microscopic examination of the ore using polished-sections, which he had learnt at ICST, to the GSFMS in 1937 (Richardson

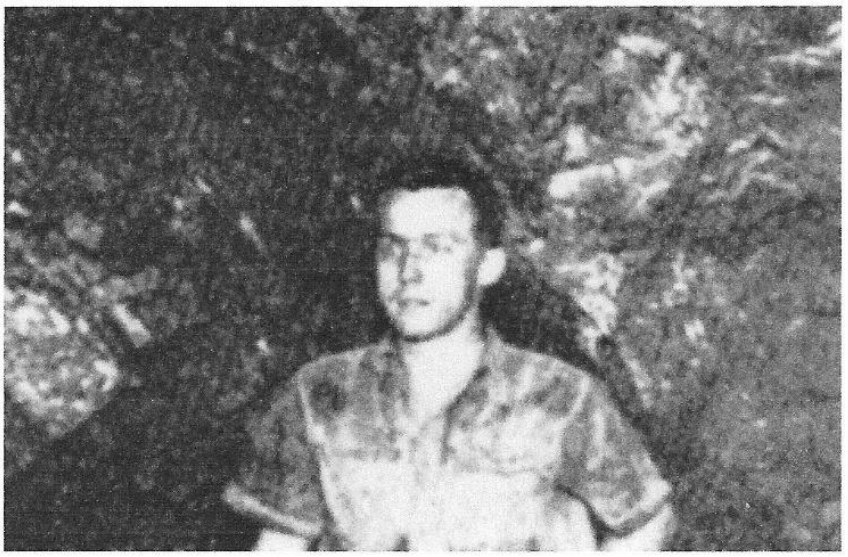

Fig. 4. Richardson underground in the Raub Australian Goldmine; photograph by E. S. Willbourn (Richardson 1939, Plate IV, Fig. 2; reproduced with permission of the Jabatan Mineral dan Geosains Malaysia). 1939b, black-and-white sketches, Fig. 35, p. 128) ${ }^{9}$. Willbourn wrote to him at Kuala Lipis 'I am gratified to have a geologist of your calibre in the Department. You have permission to combine your Government duties with the Ph.D. project which you plan' (M 31).

In September 1938, Richardson felt the time was right to apply for Fellowship of The Geological Society of London. Proposed by Ingham, Jones and Thomas Neville George (1904-1980); and seconded by Frederick Harrison Edmunds (1898-1956), Boswell and Sweeting, he was elected in November 1938 (C. Lam, pers. comm., 2013).

Towards the end of that year, two geologists: (Harold) John Service (1910-1993), a New Zealander, and Joseph Brightwell Alexander (1912-1997), a Briton, were transferred from the Gold Coast (Ghana from 1957) and Nyasaland (Malawi from 1964) Geological Surveys respectively to the GSFMS to augment its staff (Nature, 21 January 1939, p. 113). Richardson's large district (Fig. 2) was then sub-divided: he concentrated on the eastern and northern portions and Service took over the southern sector (M 62). Meanwhile, Ingham was mapping an adjoining area in the state of Perak, which lay immediately to the north-west of Richardson's in Pahang, and they undertook a ten-day field-trip together to compare findings where their two mapping-areas adjoined. Richardson's systematic mapping in Pahang continued during 1938 and 1939. This included underground investigations at the site of the old Bukit Selinsing Gold Mine which lay north of Kuala Lipis, about a day up-river by boat and, like the Raub mine, it had been worked on a small scale for hundreds of years (M 62$63)$.

As time went on, and observations began to accumulate over an ever-larger region of Pahang, Richardson began to suspect that the then-current interpretation of the geology was over-simplified and he suggested that the GSFMS might be able to make use of airphotographs (no coverage existed at that time) 'but the status quo tended to be considered as sacrosanct and [his] ideas were not well received.' (M 34).

Richardson's GSFMS memoir on the geology of the Raub Australian Gold Mine was finished in July 1939, although it was not actually on sale until December (The Straits Times, 15 December 1939, p. 2) and he sent a copy to London University as his external Ph.D. thesis

\footnotetext{
${ }^{9}$ For colour photomicrographs of polished sections of the Raub ore see Henny et al. (1995), Plates 4-6.
} 
submission (M 42). It is still regarded as a major early contribution to understanding the nature of gold mineralisation in Malaya (Gunn et al., 1993; Henny et al., 1995; ACA Howe International Ltd., 2005; Ariffin, 2012).

Following the successful completion of his probationary period, Richardson was now granted by Willbourn official GSFMS permission to marry (still a requirement in those days!). Doris accordingly left for Singapore on a Dutch vessel, MS Oranje, on 26 August 1939 and was en route when War was declared by Britain and France against Germany on $3^{\text {rd }}$ September. She arrived at Singapore City on the $20^{\text {th }}$ and their marriage took place at its Registry Office later that day.

From the early days of colonisation, it had been expected of male British residents that they would join a branch of the Volunteer Force (VF) which fulfilled a similar role to that of the Territorial Army in Britain, depending on which administrative district they were in (SS, FMS or UMS; see f.n. 4), remaining in their civilian occupations but receiving some military training at night and at weekends, as their time permitted. Because of the importance of the tin and rubber industries to the War effort, the 'key' status of men in particular occupations was now reaffirmed (The Straits Times, 3 March 1939, p. 15) and such persons were urged to remain in employment rather than return to England to enlist. Consequently, after a brief honeymoon, the Richardsons returned to Kuala Lipis, where Doris set a precedent among the other European wives by accompanying her husband on a number of his expeditions (M 64-65), as he was still completing his fieldwork in the northern part of Pahang State.

On arrival at Kuala Lipis in 1937, Richardson had joined the $4^{\text {th }}$ (Pahang) Battalion of the FMSVF, taking part in training at Kuala Lipis, or at Raub when he was working there (M 28). In January 1941, he was transferred to Batu Gajah where, as a result of his jungle experience, in mid-April he was appointed a member of a 'Special Platoon' which spent five weeks undertaking secret reconnaissance of the border-zone between the UMS of Kedah and Thailand (M 67-68). Following his return from this trip, with six-months accumulated overseas leave now overdue, he and Doris left for Australia and New Zealand. Whilst away, he took the opportunity to visit a number of university geology departments, State geological surveys, mines and industrial installations.

On their return to Batu Gajah, Richardson recommenced his geological work on $17^{\text {th }}$ November, writing-up a report on his Australian visit. He then returned to Kuala Lipis, where over the next fortnight he visited the Kramat Pulai Tin Mine, near Batu Gajah, and did some mapping at the small Tui Gold Mine, the Foo Brothers Hydraulic Gold Mine, and the Tersang Gold Mine, all situated a few kilometres north of Raub.

An atmosphere of unreality hung over Malaya. In the restaurants, clubs and places of entertainment peacetime conditions prevailed. There was no restriction on the consumption of foodstuffs. A measure to restrict the hours during which intoxicating liquor could be sold was not passed into law after long delays until November 1941. Long immunity from war had made it difficult to face realities (Percival, 1948, p. 1264).

However, on the evening of $30^{\text {th }}$ November, rumours circulated that the Japanese might attack Malaya. An impending mobilisation order was issued on December $2^{\text {nd }}$ and mobilisation followed two days later. 


\section{War}

\subsection{The fall}

'The first most people in Singapore knew of the existence of a state of war with Japan was when air raid sirens sounded at about 0415 a.m. ... Bombs were heard falling in several districts' (The Straits Times, 8 December 1941, p. 8). However, at 0025 hrs that morning, Japanese troops of the $\mathrm{XXV}^{\text {th }}$ army had already landed in strength on the east coast of southern Thailand at Singora and Patani, and in Malaya at Kota Bahru in the UMS of Kelantan (Fig. 2) where by 0100 they had established a beach-head after heavy fighting (Percival 1948, p. 1268); a formal Declaration of War by Japan eventually followed at 0600 hrs.

Percival (1948) and, more recently, Woodburn Kirby (1971), Farrell and Hunter (2002), Farrell (2005) and Thompson (2005), have documented the subsequent catastrophic loss of the Malay States and the supposed 'Island Fortress' of Singapore to the Japanese in 70 days of fighting. It can be attributed to a complete under-estimation, both by Winston Churchill and his advisors and, more locally, by some in the Malaya Command, of the capabilities of the Imperial Japanese Army (IJA) and Navy, both tactically and in the quality of their equipment (particularly the Navy's Zero fighter planes) and the fitness and fanatical fighting-spirit of their troops:

The Japanese soldiery were to a large extent hardened veterans from [fighting the Communist forces in China], extremely mobile and highly innovative. They travelled light, managed on very modest rations, used bicycles for transport, [and] were very much at home in the jungles and rubber estates. (D 14).

The possibility that an attack on Singapore Island might be mounted by troops from the north, through what was regarded by many in Malaya Command as 'impenetrable' jungle, rather than a Naval attack from the south, was generally discounted until it was denied by the facts on the ground, despite an exercise during the monsoon season of 1936-7, when the General Officer then Commanding Malaya, Maj.-Gen. William Dobbie had proved it could be done (Percival, 1948, p. 1250; Appendix A). Furthermore, many of the troops rushed from Britain, India and Australia to Singapore during the last few weeks of campaigning were unacclimatised and lacked suitable training (Percival, 1948, p. 1333). Promised supplies of additional ships, aircraft and equipment never materialised because of the competing demands of the fighting in Africa and southern Europe. Unfortunately, by mid-December:

\footnotetext{
it was now clear that we were faced by an enemy who had made a special study of bush warfare ${ }^{10} \ldots \mathrm{He}$ relied in the main on outflanking movements and on infiltration by small parties into and behind our lines. For support of his forward troops he relied on the mortar and the infantry gun rather than on longer range weapons. His snipers operated from trees. He exploited the use of fireworks. For mobility he made a wide use of civilian bicycles seized in the country. His tanks ... operated mainly on the roads. His infantry had displayed an ability to cross obstacles - rivers, swamps, jungles, etc. - more rapidly than had previously been thought possible. ... The superiority which the Japanese possessed in the air coupled with the complete absence of tanks on our side could not but have the most adverse effect. (Percival, 1948, p. 1280).
}

In consequence, Richardson's FMSVF unit had, in common with the other troops, been subject to near-continuous strategic withdrawal southwards down the peninsular. It

\footnotetext{
${ }^{10}$ In mid-1940, Willbourn had 'approached the Military Directorate in Singapore and offered the entire senior staff of the Geological Survey for intelligence duties; offer curtly refused, with thanks; [as] quite unnecessary' (M 65).
} 
eventually crossed the Causeway over the Strait of Johore onto Singapore Island on $19^{\text {th }}$ January 1942 with no specific duties assigned, and it was still waiting reassignment when the Causeway was blown up on the $31^{\text {st }}$. Richardson was discharged from the FMSVF and immediately commissioned as a $2^{\text {nd }}$ (Acting) Lt. in the Intelligence Corps. Willbourn (who had fought with distinction in WWI), was now a Captain and was reassigned to the Australian Infantry Force (AIF). Meanwhile Doris, like the other GSFMS wives, had had to make her own way south, following an evacuation order to all British women in the FMS of Perak on $3^{\text {rd }}$ January, and had since been employed in Singapore City in war-emergency jobs by various Government Departments. Now, both Richardson and his wife found themselves working in different sections of the Malaya Command headquarters: the Combined Operations Room at Sime Road and an underground bunker at Fort Canning Hill, known as the 'Battlebox', from which the defence of Singapore itself was directed (Bose, 2012).

On the $8^{\text {th }}$ February, the IJA crossed the Strait of Johore onto Singapore Island and began advancing on the City; by the $10^{\text {th }}$, Richardson was burning papers and maps at Sime Road and Doris (in common with many other European women) was ordered by Malaya Command to leave. The next day, he managed to get passages for Doris and Grace Harral, wife of GSFMS chemist, Geoffrey Milnes Harral (1912-1965), on the SS Empire Star which, although bombed while still in Singapore harbour and again en route, with the loss of 20 lives, eventually reached Fremantle, Australia. ${ }^{11}$ High-level bombing raids, low-level divebomber attacks and near-continuous shelling of the City carried on over the next few days until progressive losses and increasingly acute shortages of water, ammunition, petrol and food made surrender inevitable (Percival, 1948, pp. 1323-5): On Sunday 15 ${ }^{\text {th }}$, a cease-fire and unconditional surrender were agreed to by Lt. Gen. Arthur Ernest Percival (who had replaced Dobbie as General Officer Commanding, Malaya Command in May 1941) and Gen. Tomoyuki Yamashita of the Imperial Japanese Army, to commence at $2030 \mathrm{hrs}$.

\subsection{Changi}

The Japanese were aware that the British army had its principal base situated at the north-east corner of Singapore Island, a large complex of barracks (Selarang, Roberts, Kitchener) and other military camps occupying some $9 \mathrm{mi}^{2}\left(23 \mathrm{~km}^{2}\right)$, in an area named after the former Changi village. Using the captive army's own command structures, all troops were now directed to move to what was to become Changi POW camp, and civilian internees to the adacent Changi Gaol. ${ }^{12}$ On Tuesday $17^{\text {th }}$ those, like Richardson, who were fortunate enough to still have a car available drove the $16 \mathrm{mi}(25 \mathrm{~km})$ from Singapore City, carrying as many people as they could, but the vast majority of troops and civilians had to walk. 45,562 British, FMSVS, Australian and Indian troops were assigned to billets (Havers, 2000, p. 20); the AIF troops being housed in the former Selarang Barracks. ${ }^{13}$ Richardson (D 14-15) shared a house with 40 officers and 30 British Other Ranks; his GSFMS colleague, Service, was in

\footnotetext{
${ }^{11}$ Willbourn's wife, Jess, sailed the same day on a Chinese coaster, the Giang Bee, which was sunk by a Japanese destroyer on $13^{\text {th }}$ February with the loss of all hands.

${ }^{12}$ In mid-September 1942, Richardson learnt that his GSFMS colleagues Ingham, Alexander and Harral were all interned there (Richardson, 1945, p. 30) and their then Chief Chemist, Lt. William Albert Tooke (1910-1999) who had joined the Survey in 1939, a Reservist in the Royal Artillery, was also a POW in Changi.

${ }^{13}$ Dutch troops were added in March, following the fall of the Netherlands East Indies (Indonesia).
} 
an adjacent room. The less fortunate later arivals were in equally overcrowded tented accomodation.

Japanese liason was at the most senior officer level only, the whole camp essentially being operated under the general administration of former Malaya Command staff, and Japanese orders were transmitted to the POWs via their usual military chain of command.

Surrounded by the sea on three sides, wiring-in of the Changi camp was initially only required to cut the entire area off from the rest of the island but, later in March, camp subareas were also separated by wire and permisssion was required to go between them. Surprisingly, the wiring was undertaken by working parties of British troops who, in some cases, even had to source their own supplies from Singapore City. In practice, geography, the POW's ethnicity, and complete Japanese control of the adjacent mainland, islands and sea meant that there was simply nowhere one could realistically escape to; the very few who tried it were caught and executed. Even so, in the early days, inmates rarely saw a Japanese soldier except occasional patrols along the roads (Havers, 2000, p. 24). Apart from inadequate food supplies and water rationing, initial conditions were not too bad. Much of the work was concerned with improving the camp infrastructure, sourcing wood-supplies for fuel, watercarrying, working in the cookhouse, and so on.

Towards the end of February, Richardson met Lt. Peter Leicester (1904-1978), who was also in the Intelligence Corps. Another geologist, he had graduated from Oxford in 1925 and had subsequently worked for a few years with the Geological Survey of India and briefly the Burma Corporation Ltd. and, since 1933, with Shell in Borneo, Trinidad, India, Nigeria and latterly, at Pladju, Sumatra, in the Netherlands East Indies (information from Shell Historical Archive, mastercard Leicester). Because of their familiarity with a rice-based diet, Richardson, Service and Leicester soon found themselves showing the regular Army cooks how to make it into palatable dishes. However, what they were supplied with by the IJA was polished white rice which had lost its brown skin and most of the germ, and was therefore an inadequate source of vitamin B-1 (thiamine). Consequently, by mid-March the first cases of beriberi had begun to appear in the camp. In addition, lack of a clean water supply and waterborne sewage caused widespread dysentry, the first death occurring on $14^{\text {th }}$ March.

At this stage, no formal work demands were made of the officers, except for those accompanying work-parties engaged in bomb-damage clearance and other tasks in Singapore City. Richardson (M 137) was determined that if he could only 'keep my mind active and free' he would not feel himself to be a prisoner, and by mid-March he had begun to write notes for a book on the Geology of Malaya. A similar view was prevalent among officers in the AIF. Capitalising on the many POWs who had professional qualifications, by the beginning of April, lawyer Capt. Adrian Herbert Frederick Curlewis (1901-1985) and chemist Brigadier Harold Burfield Taylor (1890-1966) had begun to arrange a 'Command Education Scheme' which soon became known as 'Changi University.' Books of writing paper were made up from scrap, textbooks were sourced from libraries in Singapore City, and its 'departments' eventually embraced everything from basic literacy skills, to agriculture, architecture, commercial art, engineering, history, languages, law, and trade instruction.

Richardson evidently had a flair for languages and was already fluent in Bahasa Malayu. In the expectation that he would resume his professional career after the war ended, following lengthy discussions with Leicester, he decided that progress in the 'moribund' 
GSFMS would be too slow and that he should seek employment with Royal Dutch Shell. 'For this specific reason [he] began an intensive study of both Dutch and Spanish ... since Shell was very active in South America' (M 85) and he was embarked on this by $7^{\text {th }}$ April.

Having volunteered their services to the 'Engineering Faculty' of the 'University,' over the next few days, aided by textbooks such as Geology for Beginners (Watts, 1903), The Surface History of the Earth (Joly, 1930), Geomorphology (Lobeck, 1939) and the Internal Constitution of the Earth (Gutenberg, 1939), Richardson, Service and Leicester began preparing the first geology lectures. Richardson had already identified some old quarries within the camp area which could be used for field classes, as well as using the beaches to demonstrate sedimentary phenomena. His first lecture was given on $15^{\text {th }}$ April to a class of about 30: 'They seem interested. Few known any geology.' (D 19). The classes continued through June and July. Following the participation of Capt. Charles Alfred Fisher (19161982), Royal Engineers, a geographer from Cambridge University, the programme broadened into a series of additional lectures on Geology for Geographers, which began in August. Lectures on the Geology of Malaya, in which Willbourn participated, began at the same time. By now the classes had enlarged to about 38 people, among whom was another geologist, Jack Ineson (1917-1970), now $2^{\text {nd }}$ Lt. in the Royal Northumberland Fusiliers, ${ }^{14}$ who before the War had begun a PhD at Durham University 'mapping the Longmynd by traverses 10 yds apart' (D 27). When not lecturing, the group of geologists had lively discussions among themselves on topics such as the future of the GSFMS and the development of the geomorphology of Malaya (Richardson, 1947b).

By this time, a gradual depletion of numbers in the camp had begun - groups of 3000 Australian and 500 British POWs had already been moved by the IJA to unknown destinations (Burma and Thailand) in May and a further 3000 British POWs in June. On 16 ${ }^{\text {th }}$ August, a 'Special Party' which included Gen. Percival and all senior officers over the rank of Colonel and 'No. 1 Party', which included Leicester, also moved out (D 28), destined for POW camps in Formosa and Japan (Havers, 2003, p. 62). Nevertheless, the geology classes were able to continue into October: on the $7^{\text {th }}$ Richardson recorded 'Field work with Geology Class in quarry. ... good to be out on the job even in a small way' (D 31). At this time, as well as teaching structural geology, he was also preparing lectures on soils and soil erosion.

However, on the $24^{\text {th }}$ he and Fisher 'received orders that we move on overland party'. Three days later, ' $V$ ' Party, consisting of 90 officers and 560 other ranks, under the command of Lt.-Col. John Heslop Stitt, MC (b. 1898; fl. 1980), Commanding Officer of the $2^{\text {nd }}$ Battalion Gordon Highlanders, were transported northwards by rail from Singapore, crammed 25 officers per goods waggon, for a 5-day journey of some 650 miles $(1080 \mathrm{~km})$, via Kuala Lumpur and Padang Besar on the Malay/Thailand border, eventually arriving at Ban Pong, Thailand (Fig. 5), on $31^{\text {st }}$ October. They were among the 11,340 POWs sent that month ${ }^{15}$ to join the earlier working parties on construction of what would become known as the BurmaSiam [Thailand] Death Railway. Such a rapid depletion of personnel ensured that by the end

\footnotetext{
${ }^{14}$ According to Richardson's diary, Ineson was in the $4^{\text {th }}$ Norfolk Regiment, but this appears from other sources (D.A.G. 1970; Anonymous 1970; https://www.forces-war-records.co.uk) to be incorrect.

${ }^{15}$ Data from http://www.mansell.com/pow_resources/camplists/death_rr/movements_to_rr.htm. Spellings of camp names vary among authors: those adopted here generally follow this website's convention.
} 
of the month the 'University' finished, 'however, it had proved to be a useful deterrent to dispair and mental sloth ' (M 86).

\subsection{Life as a coolie}

The long sea journey round the Malayan peninsula and on to Rangoon had gradually proved increasingly difficult for Japan's merchant fleet and in June 1942 it was decided by the IJA to link the railway system of Burma with those of Thailand and Malaya by means of a new $258 \mathrm{mi}(415 \mathrm{~km})$ line from Ban Pong in Thailand to Thanbyuzayat in Burma (Fig. 5), to provide a more secure route. In earlier years, the British had contemplated a similar project but had abandoned the idea because of the extremely difficult topography (the line eventually required construction by hand of numerous cuttings and 688 bridges) and the prevalence of tropical diseases in the region to be traversed.

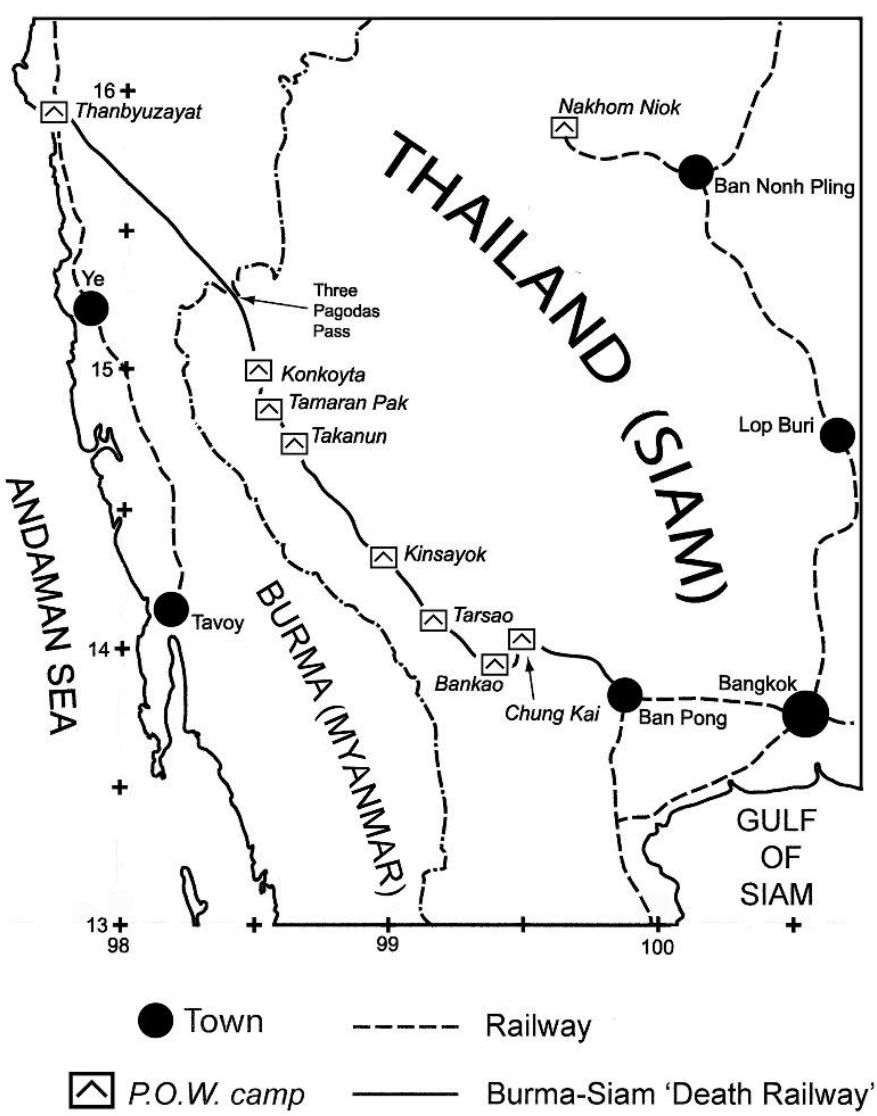

Fig. 5. Burma-Siam Railway location map (only POW camps referred to in this paper are shown).

So far as the Japanese were concerned, speed was of the essence. The impressed labour force of some 50000 POWs and, after April 1943, 270000 romusha ('economic soldiers') recruited in Malaya, Burma and Java, was intended to enable completion of the line by December 1943.

The POWs were divided into six major groups (two in Burma and four in Thailand) working under the technical direction of engineers from two Railway Regiments. To support these activities, a Japanese POW camp administration of 125 supervised a guardforce of 1300 Korean gunzoku ('civilians in military employment') who, having themselves been brutalized in their own training by the IJA, swiftly gained a reputation for a desire to humiliate the POWs in their charge, cruelty, and venality (Kinvig, 2000; Kibata, 2000). However, most feared were the Kempei (Military Police), whose authority overrode that of IJA personnel and who 'use torture freely and do not appear to be restrained by any rules of procedure or administrative regulations' (Anonymous, 1945). To make matters worse, the soldiers of the IJA had been taught nothing about the Geneva Convention on the treatment of POWs, and were indoctrinated with the idea that 'surrender in battle was totally unacceptable: it was tantamount to social suicide. ${ }^{16}$... Allied POWs were inevitably regarded as "non-persons,"

\footnotetext{
${ }^{16}$ On the night of 22 August 1945, the eve of the surrender of Singapore Island to the British, 300 Japanese officers and men committed seppuku (ritual suicide) in the lounge of the Raffles Hotel (Bose, 2012, p. 226); nor was it unknown for IJA POWs to commit suicide (Fedorowich, 2000, pp. 76, 83; Kinvig, 2000, p. 48).
} 
objects of no account, meriting no respect, creatures totally beyond the pale. Whether [they] lived or died was wholly immaterial' (M 85).

The monsoonal rains had begun and the POWs found conditions at Ban Pong very different from Changi, with bamboo huts thatched with atap (the leaves of the Nipa palm) and 'the camp was flooded, the local river having overflowed its banks. ... [Richardson's] narrow bedspace was just above waterlevel. Fortunately latrines were on somewhat higher ground and thus not badly flooded. But they were crawling with juicy well-fed fly maggots' (M 90). This was to be typical of their living conditions in the monsoon season for the next three years.

The following day, Richardson briefly met Willbourn and Service, who had come up to an adjacent camp (M 90; D 33). Within a few days, Richardson and Fisher's party had been moved on by road, continuing on foot, some $30 \mathrm{mi}(50 \mathrm{~km})$ northwards to a partially completed camp in limestone hill country at Chung Kai, and it was here that they first learnt that they would be constructing a railway line. By $9^{\text {th }}$ November, Richardson was out with three other officers, supervising 63 men building the railway embankment. He subsequently met Ineson, who had also come up with another party, and a GSFMS geologist, Frederick Harry (Henry) Fitch (1915-?1993), whom he had last seen in Singapore and who had been at the nearby Tha Muang camp since October 1942. As their movements were not at this stage restricted, on Stitt's instruction, Richardson spent several days in late November constructing a map, with compass and a make-shift plane table, of the area surrounding the camp, in case an escape attempt seemed feasable (D 36A), an activity which would have provoked immediate execution had the Japanese become aware of it.

On the $18^{\text {th }}$ December, the IJA decreed that all officers should join the working parties and Richardson now found himself participating in bridge construction: pile-driving by hand in a team of 17-18 people, generally achieving 7-10 wooden piles per day, each driven to a depth of $3-5 \mathrm{~m}$. This required ca.150 to 450 pulls on the ropes of a block-and-tackle hoist per pile, depending on the nature of the ground: 'We are now nothing but coolies, rising and eating in the dark, and returning to our hovels late in the evening ... quite impossible to do any work (i.e. private study) now' (D 42). However, at the end of January, a few days 'rest' while recovering from a bout of malaria allowed him to have further discussions with Fisher on the geomorphology of Malaya and to return to writing his paper on the topic (D 43).

During February and March, Richardson was in an advance party clearing trackways to intended new campsites at Ban Khao, Non Pradai, and Tak Ke Lain, some $30 \mathrm{mi}(50 \mathrm{~km})$ to the north, but by the end of March, the effects of malnutrition, tropical ulcers and sickness ensured his evacuation by train back to Chungkai, where he found 'enormous amounts of dipheria and diphtheric ulcers, fever, dysentry, enteritis, beriberi and general malnutrition and scabies. Scores of men reduced to skeletons' (D 54). While convalescing, he again met up with Fisher and Willbourn (D 53). The IJA allowed the 'University' scheme to restart in the evenings and Richardson began to prepare lectures on Soils and Soil Erosion, and to discuss related topics with a group of Dutch geologists and agricultural officers from the Netherlands East Indies. A rare delivery of mail brought the welcome news from home that Doris had reached Perth and that his PhD had been conferred in absentia on $3^{\text {rd }}$ February 1942 (D 57).

In mid-July, he was again sent up-country, travelling by train, motor barge and on foot to Tamaran Pak, by way of camps at Tarsao, Kinsayok, Takanun, and Konkoyta where, 
as a member of a Communications party, he now erected telegraph poles and strung wiring alongside the railway line. Somehow, he still managed to make the time to continue writing his book on Malaya, as well as a number of philosophical essays, and to make geological observations, e.g. $13^{\text {th }}$ August: 'Bands of shale and hard mudstone [interbedded] with limestone, dip 45 deg.' (D 60-66). At this time he was described by a fellow prisoner as:

\begin{abstract}
A vast, strong fellow ... he looked like a swashbuckling, Elizabethan pirate, and to highten the likeness he wore ... a magnificent, jaunty beard, and the tips of his moustache touched his eyelids. His granite physique was relieved by his ability to use his well-formed hands in a delicate and Gallic way, and also by an oddly quiet and mild voice. Of physical and mental energy he had masses - just the man needed to stir us up a bit. He was full of fever, and had a sort of controlled rigour daily, but somehow it didn't worry him (Coast, 1946, p. 144). ${ }^{17}$
\end{abstract}

On 27th November, Richardson received his first actual letter from Doris (mailed 15 months before) and learnt that she was 'working with the Taxation Office as an Auditor and four nights a week in a restaurant set up to provide funds for POW relief' (M 116).

By mid-December his whole party had completed their work (the track-laying itself had been finshed in mid-October) and they were transported by train back to Chungkai; of his original party of 104 officers, only 30 had survived. 'Apart from the usual camp chores, there was little which we really had to do; except to attempt to regain a reasonable standard of physical well being' (M 118). The camp hospital now contained over 1500 patients plus 450 convalescing from amoebic dysentery in huts outside. 'More than 100 amputations for gangrenous ulcers of the legs and arms. Other cases: ulcers, scabies, malaria, avitaminosis (pellagra etc.), debility, dysentry, etc.' (by mid-February 1944, 1059 British POWs had died out of 8000). 'We organised talks and lectures for the men, anything possible to stimulate their interest and help morale; for the lamentable truth was that many of the troops, growing up in the 'tween-war years of impoverishment, felt lost. None of their usual recreations [were] now available to them. Now they were all prisoners within an alien environment; different clime, different religion, languages of which they knew nothing, totally different cultures. Small wonder that depression stalked those unable to combat its insidious encroachment' (M 118, 121-122).

Richardson was also involved in further discussions with Willbourn on the future of the GSFMS (M 135p) and by March in a discussion group on philosophy - he eventually considered enrolling for an external BA in Philosophy on his return to London, but this idea was not in the end pursued. During the Summer, he began writing-up the Geology of N.W. Pahang and on $16^{\text {th }}$ June noted: 'Sketching limestone hills for paper on Geomorphology. Wrote paper on Geology of Mae Khlaung Valley. Learning Dutch, Soendanese and revising Malay and Jawi [the Malay version of Arabic script].' (D 84). However, by mid-January 1945, the IJA were conducting 'massive and persistent searches for papers, radios and anything incriminating' (M 125) and on the $18^{\text {th }}$ January, he prudently buried his diary ${ }^{18}$ ahead of a particularly thorough search in which he lost 'notes for stories, notes on languages, geological data, essays and the ms. of the book on Malaya' (D 89).

\footnotetext{
${ }^{17}$ He appears as 'Jim Dixon' in the account by John Coast (1916-1989) of life as a POW; pseudonyms were used to protect privacy.

${ }^{18}$ It was retrieved for him by Coast in late August 1945.
} 
In mid-February, officers were moved to Tha Muang, where he was reunited with Willbourn, Service and Fitch. They 'had many in-depth discussions regarding the Survey Department; of possible changes, development, and implementing of new policies and the expansion of surveys. We were confident that we still had a role to play if we survived the war' (M 126). While there, he noted the formation of bauxite in situ in the alluvium of the Mae Khlaung valley, between the Chung Kai and Tha Muang camps (Fig. 5), confirming Willbourn's earlier observation of its occurrence in the Tha Muang camp itself (Richardson, 1947c).

In mid-July the officers were moved by train in open trucks, via Ban Pong and Bangkok, to Ban Nonh Pling where they detrained and had a $30 \mathrm{mi}(47 \mathrm{~km})$ forced march to a camp at Nakhom Niok (Fig. 5; M 128). Fortunately, following the surrender of Japan on $16^{\text {th }}$ August 1945, they 'fed well and [their] physical condition began to improve. With leisure now [he] continued studies of the local geology and collected some interesting rock specimens for future investigation' (M 129). At the end of August, all POWs were moved to a base at Bangkok Aerodrome, and in early September flown to Mingladaung Airport, Rangoon, and placed in a Transit Camp from which, in mid-September, they began a month's voyage to Liverpool.

It was a low-key arrival - there was no official celebration of their return and POWs families were forbidden to go to the docks. The POWs themselves were instructed not to speak of their experiences in captivity either to family or friends and the release of information about them was strictly controlled (Flower, 2008). After spending the night in a military transit camp, on the following day, $22^{\text {nd }}$ October 1945, Richardson was delivered to the address in Ewell, Surrey, where his parents were now living. Doris was also there, having arrived from Sydney on $10^{\text {th }}$ September.

He had survived between 35-40 bouts of benign tertian malaria plus dengue, hookworm, beriberi, general avitaminosis, gastro-enteritis, tropical ulcers, scabies, ringworm, and boils. Very fortunately, he had not caught dipheria, cholera, malign tertian malaria nor amoebic dysentery (M 137), which contributed to over 12000 deaths among the POWs and perhaps 90000 among the romusha (Kinvig, 2000). Surprisingly, Richardson's only followup from the Army Medical Services was a small supply of anti-malarial pills. There was no psychological counselling for any POW. As Flower (2008, p. 64) remarked 'the attitude of the British Authorities towards the Far-Eastern POWs has been at best ambivalent: the surrender of Hong Kong and Singapore cast a long shadow.'

Before taking a six-week period of vacation with Doris in Devon, Richardson had contacted the Colonial Office, the Royal Dutch-Shell Group and the Geological Survey of Great Britain regarding employment. As he was now technically on leave from the GSFMS and awaiting reassignment, early in the New Year he enrolled as a post-graduate student for three months at the ICST in order to write his Diploma of Imperial College thesis on The Geology of North-West Pahang. In addition, he began to write-up his pre-War Weald Research Committee work (Rogers and Richardson, 1947; Richardson, 1946a, 1947a) and studies carried out in Malaysia and Thailand (1947b-g). On $21^{\text {st }}$ Febuary 1946, he gave a lecture, The Rape of the Earth, to the Scientific Society of the Royal College of Science on the consequences of practices leading to soil erosion (Richardson, 1946b), a subject on which he had first lectured whilst in the POW camps. 
Except for Willbourn, who was now transferred to the Directorate of Overseas Geological Surveys in London, all Richardson's former colleagues: Ingham, Service, Alexander, Tooke, Harrell and Fitch returned to Malaysia. Very probably, life in England offered little attraction. The writer, James G. Ballard (1930-2009), repatriated after internment as a teenager in Lunghua Camp, Shanghai, wrote:

Looking at the English people around me, it was impossible to believe they had won the war ... They were clearly exhausted by the war, and expected little of the future. Everything was rationed - food, clothing, petrol - or simply unobtainable. ... More importantly, hope itself was rationed, and peoples spirits were bent low. (Ballard, 2008, p. 123).

In the end, Richardson decided to resign from the Colonial Service as he 'had developed serious doubts about the long term prospects. There was altogether too much awaiting dead men's shoes. There was no clear indication that competence could expect advance over seniority or playing bridge with the right people' (M 139). Consequently, in March 1946, he began work with Shell, initially at the offices of its parent company, the Bataafse Petroleum Maatschappij (BPM), in Teddington, Middlesex. While awaiting assignment, he undertook field mapping in Dorset, Derbyshire, Gloucestershire and Hertfordshire before transferring to BPM's Training Geology Department in The Hague, Netherlands, in July. He then spent time on a drilling site at Coevorder, Eastern Netherlands, before being transferred as a Geologist to a Shell subsidiary, the Caribbean Petroleum Co. (CPC), in Maracaibo, Venezuela in November 1946 (M 141; information from Shell Historical Archive, mastercard Richardson). The CPC had made the first significant discovery of oil in the country in 1914, with the well Zumaque-1, in what was to become the Mene Grande Oilfield (Fig. 6).

Unfortunately, Doris had to stay in England, where their son (John Victor) Gwyn Richardson was born in Epsom, Surrey, on 22 July 1946. Although his father visited briefly from The Hague, they were not yet able to join him owing to a lack of married quarters.

\section{Venezuela}

Following Richardson's arrival in Maracaibo, once the administrative formalities were complete he began his geological familiarisation with local fieldwork in the area, followed by three months working with a contract seismic party in the foothills of the Andes, east of the town of San Antonio del Táchira (Fig. 6) in the headwaters of the Orinoco river in the Estado Táchira (Táchira State). Although the jungle was not as dense as that in Malaya, conditions were similar, with high temperatures and humidity, and cloud-cover and drizzle or thunderstorms on $25 \%$ of the days.

On return, he went to Caracas for a course in photogeology before being temporarily seconded for six weeks in

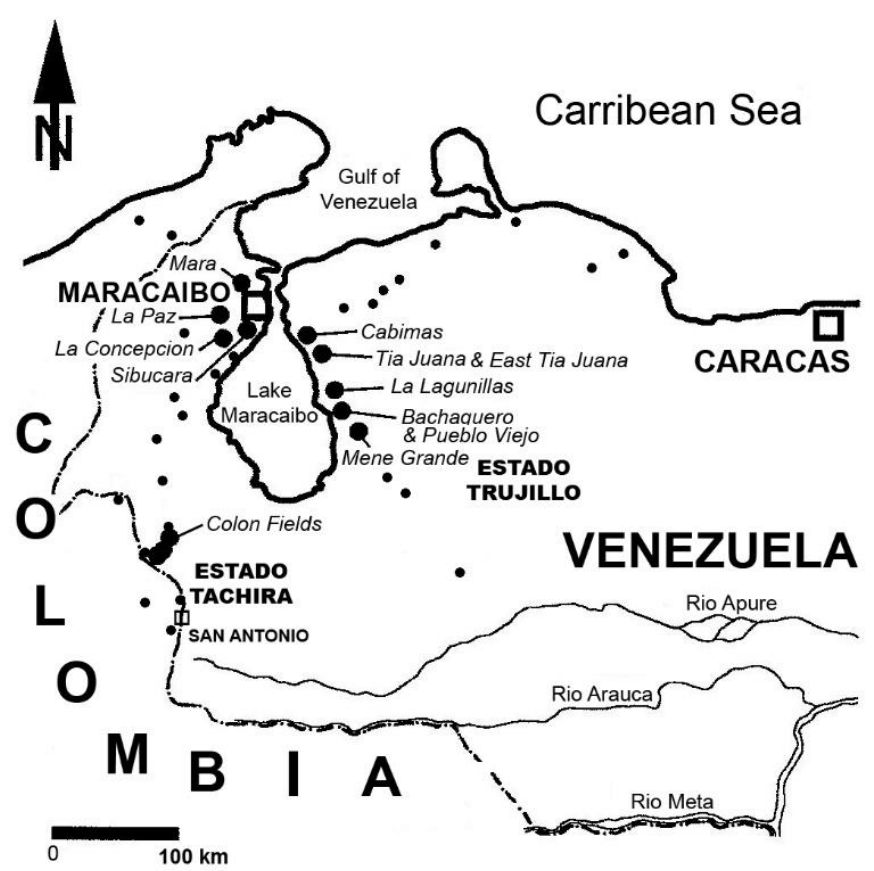

Fig. 6. West Venezuela oilfield location map. 
mid-1947 to the Exploitation Engineering Department (EED), which was based in Maracaibo, working in the Bachaquero oilfield (Fig. 6) in order to acquire further familiarity with drilling methods and well-site geology. However, 'having realised that [he] had had just about enough of jungle life', in August he was allowed to transfer to the EED (M 153), as a Production (Exploitation) Geologist, and Doris and Gwyn were at last able to join him. Following their arrival, after a short spell in the Colón district (Fig. 6), where the Los Mamueles and Las Cruces fields were located, he returned to the Maracaibo office.

Three short papers which he had written on aspects of the geology of Malaysia and Thailand (Richardson 1947c-e) were read in his absence at a meeting of the Institution of Mining and Metallurgy in London on $16^{\text {th }}$ October 1947. It was attended by both Willbourn and Scrivenor, who paid tribute to his 'enthusiasm that could surmount even the difficulties and trials of Japanese prison-camps and keep alive his interest in geological problems' (Willbourn, 1947).

In January 1948, Richardson and his family were transferred to La Concepción, Shell's HQ for the work on the western side of Lake Maracaibo, as a District Production Geologist, often finding himself on permanent 24-hour callout when well-logging, coring or testing was going on in the La Concepción, La Paz or Mara Fields (Fig. 6). Very sadly, Gwyn died of severe gastro-enteritis in July 1948 (M 159) whilst he was away (M. Maher, pers. comm., 2013). The unexpected arrival of the typescript of his second Malaysian memoir, which he had written in 1940, for editing prior to publication by what had now become the Geological Survey of the Federation of Malaya (GSFM) following restructuring of the territories of Peninsula Malaya in 1948 (Richardson, 1950), must have come as a welcome distraction.

Just before Christmas, the Richardsons were transferred to Lagunillas on the eastern side of Lake Maracaibo, where he was responsible for production geology in the Lagunillas, Tia Juana and Bachaquero Fields, and wildcat drilling in Cabimas (Fig. 6), and Doris was employed by the Company as an auditor. Then, in August 1949, they were transferred to Caracas where he led a review of Shell's interests in the oil and gas fields of Eastern Venezuela, as CPC's had hitherto been confined to the west (Staff of the Caribbean Petroleum Company, 1948). This provided him with an opportunity to become familiar with the Orinoco Heavy-oil Belt.

Following periods of leave and three months assignment at BPM in The Hague, on return to Venezuela, Richardson became Production Geologist for the Mene Grande Field and was also responsible for the Bachaquero Field and wildcat drilling in the Estado Trujillo, while Doris became Confidential Secretary to the Camp Superintendent. In February 1951, they returned to Maracaibo where he became successively, Senior Exploitation Engineer (1950-56), Senior Subsurface Geologist (1956-58) and Senior Production Geologist (195862) responsible for all Shell's fields in the Maracaibo Basin (Shell Historical Archive, mastercard Richardson).

In 1954 Shell's interests in Venezuela became incorporated in Compañía Shell de Venezuela and as it began reducing its numbers of expatriate staff, Doris joined the U.S. Foreign Service and became confidential secretary to a succession of U.S. Consuls and ViceConsuls (M 168). Richardson now oversaw the work of about a dozen geologists (each one being responsible for subsurface geology in one of the production districts); drilling rigs 
involved in exploration, appraisal and development; special studies evaluating new discoveries by competitors; and negotiation of Offset Drilling Production and Development Agreements in new production areas which were adjacent to older concessions held by other companies. When the Suez Canal was closed in 1956, a major increase in production was suddently required and EED had to delineate suitable targets and undertake the development drilling. Over a five-month period, the time required to sink an $8000 \mathrm{ft}(2440 \mathrm{~m})$ well was reduced from around 30 days to 10 , and by 1957 the production rate had reached $1 \mathrm{M} \mathrm{bbl} /$ day (M 171-2).

In November 1959, Richardson was co-author of a talk on the geology of the basement of the west side of Lake Maracaibo (Guariguata and Richardson, 1959) at the Third Venezuelan Geological Congress and, in the Summer of 1961, he attended a six-week structural geology course at the Shell Development Company's Houston Laboratory. This included a two-week geological tour through parts of the USA and western Canada; 'it was fascinating both geologically and also as a painter's paradise: [his] note books were filled with pencil sketches' (M 183).

Richardson's interest in art had first manifested itself when he was at school but he had not really exercised it since. Then, in 1953, partly as a counter-balance to pressures of work, he began to make pencil sketches. This gradually broadened into experimentation with charcoal, pastels, oil-painting and aquarelle. By 1956, Doris 'realising that [he] was serious about this activity ... presented [him] with a three-year correspondence course' and Richardson would get up at around 0430 am and work at his art assignments for up to two hours daily before going to the office. At the end of the course, he enrolled in another in Commercial Art and Design (M 191).

When, in 1961, Richardson informed Shell that he wished to retire, he was initially not believed (M 192). Despite the fact that he and Doris 'had not sought any front-line exposure within the organisation and maintained a discrete profile' (M 190), he was rated a top-performing, thoroughly competent Senior Production Geologist and an excellent leader 'well liked and respected by his staff', although showing an occasional 'rather intense dissatisfaction with some of his very weak staff.' (information from Shell Historical Archive, mastercard Richardson; P. Baxendell, pers. comm., 2013). However, he eventually negotiated release, and he and Doris left Venezuela in late October 1962.

\section{In transition}

The Richardsons spent much of the next few years in travelling widely (M 193-217, 222-4) in North America, Europe, Iran, India, Brunei, Fiji, Australia and New Zealand. They visited Batu Gajah and the new headquarters of the GSFM in Ipoh, Malaya, and Kanchanaburi and Chungkai in Thailand in 1966; and in 1971 even spent a week in Japan. Between January 1965 and July 1976, they based themselves in Tucson, Arizona, where Richardson taught art, and in 1969 he was invited to be Director of a Summer School run by the Haliburton [Highlands] Guild of Fine Arts, Ontario, where he added driftwood sculpture to his interests.

\section{Geology resumed}

Richardson's sister and her family had moved to Perth in 1947, followed by their parents in 1957; his mother died in 1960 and his father two years later. In 1970, Richardson and Doris 
were still wondering where to settle for their 'ultimate retirement' and decided to revisit Perth. It would be his fourth visit to Australia and Doris's fifth. The Australian nickel boom had just reached its height, with 90 percent of the deposits being found in Western Australia. As his last work in the minerals field had been in 1941, he was curious to see if he 'could get a job and if [he] was still capable of concentrated technical work over prolonged periods' (M 217). Having answered two advertisments, he soon joined a consultancy, Layton and Associates Pty. Ltd. (Dr. Bill Layton, based in Brisbane; and Drs. Brian Welch and Lawrie Davidson in Perth), which was engaged in mineral exploration. The firm advised small exploration companies established during the nickel boom, who often did not have their own geoscience experts, regarding the best methods of photogeology, mapping, gravimeter surveys and geochemical sampling, while recommending that they should always take a cautious approach to diamond drilling until real potential was established. His first task was the preparation of a Review of the Mining Industry and Potential of Western Australia; this was followed by investigations of potential tungsten, tantalum, nickel, gold, iron and copper deposits; and assessment of ancient beach deposits for rutile, ilmenite, zircon and rare-earth minerals. He later also advised on potential oil and gas exploration areas. When work began to tail-off in September 1971, he and Doris returned to the USA but in September 1974 they decided to return permanently to Australia.

Richardson resumed consultancy with Layton and Associates in Perth and subsequently worked on both onshore and offshore petroleum exploration and mineral projects, including diamond, gold, uranium and coal investigations; as well as pioneering the use of Earth Resources Technical Satellite (Landsat) imagery in mineral exploration in Australia, Indonesia, Thailand and Papua New Guinea. A colleague, who worked with him, recalls him as 'an extraordinary person, a fine geologist, and a marvellous mentor to the young graduates we were employing at the time. ... He was the original recycler - perhaps an instinctive reaction after all his years of making-do while a POW. All the drafts of his reports came to the Layton typists' desks written on the inside of opened-out envelopes that he had scavenged from the office bins. He was the master of the "cut and paste" technique in compiling draft reports' (L. Davidson, pers. comm., 2013).

Richardson finally left them in March 1982, then spent a year with another consultancy, ECL Australia Pty. Ltd., involved in petroleum, coal and uranium exploration, before 'retiring' to work part-time as an independent petroleum consultant (M 217-221a, 225$6)$.

Having moved home to Maida Vale in Kalamunda Shire, on the outskirts of Perth, in October 1976, he was now able to give more time to art, becoming President of the Kalamunda and Districts Arts and Crafts Group (July 1977-80) with Doris as its Hon. Treasurer (July 1979-80). They remained members until 1991 and he subsequently wrote a history of the society (Richardson, 1993a). He was one of several people in the Arts and Crafts Group asked by the Kalamunda and Districts Historical Society to provide illustrations for a history of the development of the community (Harper-Nelson, 1978); and through this, he became involved with the Society, as its Archivist, Publicity Officer, Vice-President and President (1977-80), while Doris was again Treasurer.

In 1982, they both became members of the Royal Western Australian Historical Society (RWAHS) and assisted with several projects to document the graves of early settler 
burials. In March 1983, Richardson began three years of work with David Davies, Conservation and Land Management Department Ranger in charge of the East Perth Cemetry, the remains of the burial ground of the original Swan River Colony (which was renamed Western Australia in 1832), to record the details of the 780 graves still extant (Richardson and Patterson, 1985; Richardson and Davies, 1986). The Colony was officially founded in October 1828 and the cemetry opened in 1829 for the burial of pioneer settlers, although a few burials continued up to 1923. These reports led the RWAHS to commission similar studies of five more pioneer cemetries in the Shires of York and Beverley. Doris recorded the information, while he made pen-and-ink drawings of the sites and headstones (Taggart, 1993; Richardson, 1988, 1993b; Richardson and Richardson, 1989a-c, 1989-1991). Three further local history studies followed (Richardson, 1995, 1998; Richardson and Burgess, 1998).

Richardson finally retired from consultancy in 1989, but kept up his interest in geology through the journals of the many societies of which he was a member, receiving a 50-year Legion of Honour Certificate from the Society of Petroleum Engineers in 1997 and a 60-year Membership certificate from the Australian Institute of Mining and Metallurgy in 2002.

Doris died in 2003 and Richardson on 17 August 2007. Both were cremated at Karrakatta Cemetry in Perth, W.A. He 'had quite a machismo style and a more risque approach to life that was part of his adventuring life throughout. War had hardened his attitude to life, Doris mentioned a few times. He remained outspoken on many political and social issues. He did not "suffer fools gladly" and bemoaned "homo sapiens", questioning the latter description for its accuracy ... agnostic, if not atheist, he was given to ribald humour, was never an apologist, always spoke his mind and never could you find a man with more determination, not easily swayed by public or personal opinion. [She] was his demure counterpart ... a warm and equally determined person, perhaps more of a diplomat and more accepting of differences. They were inveterate readers and thinkers, any subject open for discussion. ... It is rare in life to meet such people, who radiate wisdom and courage.' (A. Glover, pers. comms., 2013). The Geologists' Association is honoured both by his 73-year committment to it, despite his many years of absence from England, and the donation which enabled the Richardson Award to be established.

\section{Acknowledgements}

Details about Richardson's life and career proved extremely elusive and this work could not have been completed without considerable help from both people and the invaluable website http://www.ancestry.co.uk/. I particularly wish to thank Andrew Glover, Jim Richardson's Executor, for giving me his personal copy of Richardson's 1985 memoir and for permission to quote excerpts both from this and his wartime diary; and to Yvette Thompson and Jenny Kohlen for making the suggestion that I should get a request into the 'Can You Help?' page of The West Australian, and then assisting me to do so, which resulted in my making a lot of useful contacts. So, my grateful thanks go to the following people and organisations - in England: Anne Barrett, Sir Peter Baxendell, Wendy Hawke, Jonathan Larwood, Sir Mark Moody-Stuart, Edmund Nickless, Mike Ridd, Sarah Stafford, Doug Stimson and the Library of the Imperial War Museum, London; and in Australia: Gay Bridgement, David Baylis, Charles Butt, Lawrie Davidson, Natalie Dorsett, John Ellison, Andrew Glover, Jenny Kohlen, 
David LeRoy, Marcia Maher, Phil Playford, John Pollock, Yvette Thompson, Brian Welch, Frank West, David Whiteford and Jean Yates; and to Caroline Lam (Archivist, Geological Society of London); Rosalie van Egmond (Historical Archive Administrator, Shell International B.V., The Hague); Dato' Yunus Bin Abdul Razak, Habibah Tahir and Mohd Shafiq Farhan bin Mohd Zainudin of the Jabatan Mineral dan Geosains Malaysia (Minerals and Geoscience Department Malaysia); and the Arkib Negara Malaysia (National Archives of Malaysia). Dr. Rob Havers and two anonymous referees are thanked for their helpful comments on the manuscript.

\section{References}

ACA Howe International Ltd. 2005. Review of proposed CIL plant operations and the exploration potential of mineral properties located in the State of Pahang, Malaysia. Peninsular Gold Limited. Introduction of 33,951,596 ordinary shares of no par value and Admission to trading on AIM. Nabarro Wells \& Co., London, pp. 19-82. http://www.peninsular. gold/docs/admission_doc.pdf.

Anonymous. 1900. Of William Bibby. Straits Times, May 3, 1900, p. 3.

Anonymous. 1945. The Kempei in Japanese-occupied territory. Current Intelligence Study Number 29. R \& A 3186S. United States Office of Strategic Services, Research and Analysis Branch. 5 pp. http://www.foia.cia.gov/sites/default/files/ document.../ DOC_0000709800.pdf.

Anonymous. 1970. Dr. J. Ineson - Obituary. International Association of Scientific Hydrology Bulletin, 15 (4), 127-128.

Anonymous. 2004. Dr Jim at 90 shuns fuss as usual. Kalamunda Reporter, June 1, 2004, p. 4.

Ariffin, K.S. 2012. Mesothermal Lode Gold Deposit Central Belt Peninsular Malaysia. In: Dar, I.A (Ed.), Earth Sciences, inTech, Rijeka. pp. 313-342. http://www.intechopen.com/ download/pdf/27599.

Bose, R. 2012. Singapore at War. Secrets from the fall, liberation and aftermath of WWII. Marshall Cavendish, Singapore, pp. 1-122.

Bull, A.J., Gossling, F., Green, J.F.N., Hayward, H.A., Turner, E.A., Wooldridge, S.W. 1934. Weald Research Committee Report no. 18. The River Mole: its Physiography and Superficial Deposits. Proceedings of the Geologists' Association 45, 35-69.

Chapman, F.S. 1949. The Jungle is Neutral. Chatto and Windus, London. 436 pp.

Coast, J. 1946. Railroad of Death. The Commodore Press, London. 256 pp.

D.A.G. 1970. Jack Ineson (1917-1970). Quarterly Journal of Engineering Geology 3, 71-72.

Eagling, G. 2010. Dr. Bernard Pitcher BSc ARCS (1909-2000) First congenitally deaf person to hold a Ph.D. Sussex Deaf History. http://www.sussexdeafhistory.org.uk/ page_id_62_path_0p34p.aspx.

Evans, P. 1932. Geological Surveying in Jungle Country (Section of Geology. Presidential Address). Proceedings of the Nineteenth Indian Science Congress. The Asiatic Society of Bengal, Calcutta, pp. 337-369. 
Farrell, B.P. 2005. The defense and fall of Singapore 1940-1942. Tempus Publishing, Stroud, $480 \mathrm{pp}$.

Farrell B., Hunter, S. 2002. Sixty years on: The fall of Singapore revisited. Eastern Universities Press, Singapore, 359 pp.

Fedorowich, K. 2000. Understanding the enemy: Military intelligence, political warfare and Japanese prisoners of war in Australia, 1942-45. In: Towle, P., Kosuge, M., Kibata, Y. (Eds.). Japanese Prisoners of War. Hambledon and London, London. pp. 60-86.

Findlay, L. 2007. Geologist, survivor and history lover [obituary]. The West Australian, September 21, 2007, p. 57.

Flower, S.J. 2008. Memory and the prisoner of war experience. In: Forgotten captives in Japanese-occupied Asia. Hack, K., Blackburn, K. (Eds.). Routledge, Abingdon. pp. 5772.

Guariguata, R.C., Richardson, J.A. 1959. El Basamento en el Oeste del Lago de Maracaibo [abstract]. III Congreso Geológico Venezolano, 22-29 de Noviembre. Caracas. p. 26.

Gunn, A.G., Halim bin Hamzah, Ab., Ponar Sinjeng, P. 1993. Geochemical and mineralogical studies at the Kim Chuan gold mine, Raub, Pahang, Malaysia. Geological Survey of Malaysia - British Geological Survey Gold Sub-Programme Report. Jabatan Penyiasatan Kajibumi [Geological Survey of Malaysia], Ipoh. pp. 1-46.

Gutenberg, B. (Ed.). 1939. Internal Constitution of the Earth. McGraw-Hill, New York. 413 pp.

Harper-Nelson, J. (Ed.) 1978. Kalamunda and District Historical Society presents A line on Kalamunda. Nine Club, East Perth, W.A. 75 pp.

Havers, R. 2000. The Changi POW Camp and the Burma-Thailand Railway. In: Towle, P., Kosuge, M., Kibata, Y. (Eds.). Japanese Prisoners of War. Hambledon and London, London. pp. 17-36

Havers, R.P.W. 2003. Reassessing the Japanese Prisoner of War Experience. The Changi POW Camp, Singapore, 1942-5. RoutledgeCurzon, Abingdon. 216 pp.

Henny, P.J., Styles, M.T., Wetton, P.D., Bland, D.J. 1995. Characterisation of gold from the Raub area, Pahang, Malaysia. Overseas Geology Series Technical Report. British Geological Survey, Keyworth, Nottingham. pp. 1-70.

H.D.T. 1958. Leonard Miles Parsons [obituary]. Proceedings of the Geological Society, London, no. 1563, p. 128.

Joly, J. 1930. The Surface History of the Earth. Clarendon Press, Oxford. 211 pp.

Kibata, Y. 2000. Japanese Treatment of British Prisoners of War: The Historical Context. In: Towle, P., Kosuge, M., Kibata, Y. (Eds.). Japanese Prisoners of War. Hambledon and London, London. pp. 135-147. 
Kinvig, C. 2000. Allied POWs and the Burma-Thailand Railway. In: Towle, P., Kosuge, M., Kibata, Y. (Eds.). Japanese Prisoners of War. Hambledon and London, London. pp. 3757.

Kirkaldy, J.F. 1958. The work of the Weald Research Committee. The South-Eastern Naturalist and Antiquary 62, 14-25.

Leake, B.E., Bishop, A.C., Howarth, R.J. 2013. The Wyley History of the Geologists' Association in the 50 years 1858-2008. The Geologists' Association, London. 137 pp.

Lobeck, A.K. 1939. Geomorphology: An introduction to the study of landscapes. McGrawHill Book Co., London. 731 pp.

Middlemiss, F.A. 1975. Studies in the sedimentation of the Lower Greensand of the Weald. 1875-1975: a review and commentary. Proceedings of the Geologists' Association 86, 457-473.

Percival, A.E. 1948. Operations of Malaya Command, from 8th December, 1941 to 15 th February, 1942. The London Gazette [Second Supplement], February 26. pp. 12451346.

Richardson, J.A. 1939a. Prospecting and the geologist. The Elliottonian, 192 (Mid-Summer 1939), pp. 23-24.

Richardson, J.A. 1939b. The geology and mineral resources of the neighbourhood of Raub, Pahang, Federated Malay States, with an Account of the Raub Australian Gold Mine. [Memoir no. 3 (New Series)]. Geological Survey Department, Federated Malay States, Batu Gajah. 166 pp.

Richardson, J.A. 1941. The coal veins of British Malaya. Geological Magazine 78, 451-462.

Richardson, J.A. 1945. [Transcript of war-time diary, 1941-45]. Catalogue no. 1705 87/58/1. Imperial War Museum, London. 89 pp.

Richardson, J.A. 1946a. The stratigraphy and structure of the Arenaceous Formation of the Main Range Foothills, F.M.S. Geological Magazine 83, 217-229.

Richardson, J.A. 1946b. The Rape of the Earth. The Scientific Journal of the Royal College of Science 16, 51-62.

Richardson, J.A. 1947a. Chert formation in the Bargate Beds of the Churt neighbourhood, Surrey (Weald Research Committee Report no. 35). Proceedings of the Geologists' Association 58, 161-177.

Richardson, J.A. 1947b. An outline of the geomorphological evolution of British Malaya. Geological Magazine 84, 129-144.

Richardson, J.A. 1947c. The origin of the Amphibolite-schist Series of Pahang, Malaya. Geological Magazine 84, 241-249.

Richardson, J.A. 1947d. Facies change and lithological variation in the Permocarboniferous Formation of North-West Pahang and South-West Kelantan, Malaya. Geological Magazine 84, 281-288. 
Richardson, J.A. 1947e. Bauxite formed in situ in Alluvium and lateritization of Alluvium and Limestone in the Mae Khlaung and Khwae Noi Valleys, Siam. Bulletin of the Institution of Mining and Metallurgy 490, 13-17.

Richardson, J.A. 1947f. Alluvial cinnabar in North-West Pahang, Malaya. Bulletin of the Institution of Mining and Metallurgy 490, 19-22.

Richardson, J.A. 1947g. Economic importance of jointing in the limestone bedrock of two alluvial goldmines, Pahang, Malaya. Bulletin of the Institution of Mining and Metallurgy 490, 23-28.

Richardson, J.A. 1950. The geology and mineral resources of the neighbourhood of Chegar Perah and Merapoh, Pahang. Memoir no. 4 (New Series). Geological Survey Department, Federation of Malaya, Batu Gajah. 155 pp.

Richardson, J.A. 1985. Memories - Bitter Sweet. Kalamunda, Perth, Western Australia: [Unpublished manuscript, July 1985; Geological Society of London Archives ref. no. A/2014/12]. 239 pp.

Richardson, J.A. 1988. The Old Cemetry, York, W.A.: basic data and a pictorial record. J.A. Richardson, Maida Vale, W.A. 2 vols. 67, 380 pp. [State Library of Western Australia, Perth, W.A. Call no. Q 929.5 RIC].

Richardson, J.A. 1993a. Twenty Years of Creative Endeavour: The story of the Kalamunda and Districts Arts and Crafts Group Inc. Kalamunda and Districts Arts and Crafts Group, Kalamunda, W.A. 113 pp.

Richardson, J.A. 1993b. A look at six pioneer cemeteries in Western Australia. J.A. Richardson, Maida Vale, W.A. 65 pp. [State Library of Western Australia, Perth, W.A. Call no. Q 929.5 RIC].

Richardson, J.A. 1995. Kalamunda Shire: Developments from 1950-1970 and onwards. J.A. Richardson, Maida Vale, W.A. 29 pp. [State Library of Western Australia, Perth, W.A. Call no. Q 994.12 KAL].

Richardson, J.A. 1998. Saint Swithun's Anglican Church Lesmurdie: a living heritage. St. Swithun's Church Council, Lesmurdie, W.A. 146 pp.

Richardson, J.A., Burgess, B.G. 1998. The Kalamunda and Districts Agricultural Society Inc. approaching its centennial. Kalamunda and Districts Agricultural Society, Kalamunda, W.A. 75 pp.

Richardson, J.A., Davies, D. 1986. East Perth Cemetery: resting place of Western Australian pioneers. Royal Western Australian Historical Society, Perth, W.A. 3 vols. 213, 127, 332 pp. [State Library of Western Australia, Perth, W.A. Call no. Q 929.5 RIC].

Richardson, J.A., Patterson, R.V. 1985. East Perth cemetery [1:2000 map]. Royal Western Australian Historical Society, Perth, W.A. [State Library of Western Australia, Perth, W.A. Call no. 2/5/24].

Richardson, J.A., Richardson, D.M. 1989a. St. Paul's Church and cemetery, km 26 York (top) -Beverley Road, Edwards Crossing, W.A.: basic data and a pictorial record. 2 vols. J.A. 
Richardson, Maida Vale, W.A. 2 vols. 4, 25 pp. [State Library of Western Australia, Perth, W.A. Call no. Q 929.5 RIC].

Richardson, J.A., Richardson, D.M. 1989b. St. Peter's Church and cemetery, Gilgering, W.A.: basic data and a pictorial record. J.A. Richardson, Maida Vale, W.A. 2 vols. 14, 73 pp. [State Library of Western Australia, Perth, W.A. Call no. Q 929.5 RIC].

Richardson, J.A., Richardson, D.M. 1989c. Pioneers' Cemetery site, York, W.A.: basic data and a pictorial record. J.A. Richardson, Maida Vale, W.A. 24 pp. [State Library of Western Australia, Perth, W.A. Call no. Q 929.5 RIC].

Richardson, J.A., Richardson, D.M. 1989-1991. Green Hills Cemetry: km 25 YorkQuairading Road, W.A.: basic data and a pictorial record. J.A. Richardson, Maida Vale, W.A. 3 vols. 5, 24, 8 pp. [State Library of Western Australia, Perth, W.A. Call no. Q 929.5 RIC].

Rogers, H.S., Richardson, J.A. 1947. Mechanical analysis of the Lower Greensand of northwest Surrey. (Weald Research Committee Report no. 38). Proceedings of the Geologists' Association 58, 259-269.

Scrivenor, J.B. 1928. The Geology of Malayan Ore-Deposits. MacMillan, London. 216 pp.

Staff of the Caribbean Petroleum Company. 1948. Oil fields of Royal Dutch-Shell Group in Western Venezuela. Schaub, H.P. (Ed.). Bulletin of the American Association of Petroleum Geologists 32, 517-628.

Sweeting, G.S. (Ed). 1958. The Geologists' Association 1858-1958. A history of the first hundred years. The Geologists' Association, London. 165 pp.

Taggart, T. 1993. Death is no stranger to cemetery historian. Hills Gazette, April 11, 1993, p. 10.

Thompson, P. 2005. The Battle for Singapore: The true story of Britain's greatest military disaster. Portrait Books, London. 678 pp.

Towle, P. 2000. The Japanese Army and Prisoners of War. In: Towle, P., Kosuge, M., Kibata, Y. (Eds.). Japanese Prisoners of War. Hambledon and London, London. pp. 1-16.

W.B.T. 1954. Dr. Arthur J. Maslen [obituary]. Proceedings of the Geological Society of London, no. 1512, 138.

Watson, J.H. (Ed.). 1947. Register of the Associates and Old Students of the Royal School of Mines. Royal School of Mines (Old Students) Association, London. 275 pp.

Watts, W.W. 1903. Geology for Beginners. Macmillan, London. 352 pp.

Willbourn, E.S. 1947. Contributed remarks. Bulletin of the Institution of Mining and Metallurgy, no. 493, 44-45.

Williams, D. 1963. History of the Department of Geology Royal School of Mines (1906-57). Unpublished manuscript. $172 \mathrm{pp}$.

Woodburn Kirby, S. 1971. Singapore: The chain of disaster. Cassell, London. 270 pp. 
Yeap, E.B. 1993. Tin and gold mineralisations in Peninsular Malaysia and their relationships to the tectonic development. Journal of Southeast Asian Earth Sciences 8, 329-348. 